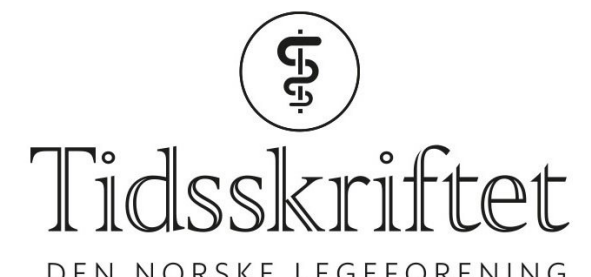

DEN NORSKE LEGEFORENING

\title{
Kroppen er rar
}

LEGELIVET

\section{KAVEH RASHIDI}

E-post: kavehrashidi@gmail.com

Kaveh Rashidi (f. 1988) er fastlege på Schouslegene, universitetslektor ved Universitetet i Oslo og forfatter.

Vi fastleger møter ofte pasienter med symptomer som verken vi eller noen andre klarer å forklare. Kanskje vi av og til blir nødt til å si: «Vet ikke, menneskekroppen er bare rar noen ganger.»

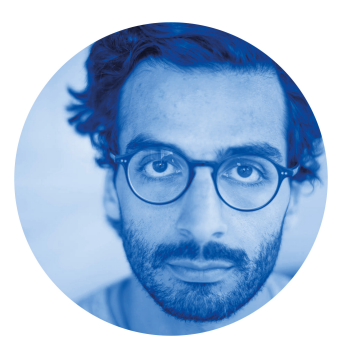

Fysiske smerter, svimmelhet og tretthet - det er bare noen få eksempler på symptomer pasienter opplever en gang iblant. For noen blir det så uttalt eller så langvarig at de oppsøker fastlegen. Ofte finner vi en årsak i løpet av et par konsultasjoner, andre ganger forsvinner symptomene av seg selv. Da pleier både pasient og lege å bli fornøyd. Andre ganger er det mer komplisert.

De kompliserte symptombildene kan være frustrerende og tære på både lege og pasient. Men legeyrket hadde vært ganske kjedelig hvis vi alltid jobbet med enkle diagnoser. Å løse medisinske mysterier er en av gledene ved yrket. Men hva hvis de ikke lar seg løse?

Hva hvis månedene går og alt vi har er normale prøver? Når blod, urin og avføring er blitt sendt til laboratorier på kryss og tvers av landet og alle prøvesvar er normale. Når røntgen-, ultralyd-, CT- og MR-undersøkelser alle viser strukturer så flotte at de kunne blitt brukt som normalbilder i lærebøkene. Når man har bedt om hjelp hos titalls spesialister, som ikke har noe å bidra med. Ja, når selv spytt og svette er blitt samlet i håp om å treffe en usannsynlig diagnose - men ingenting slår ut. Hva gjør vi?

På et eller annet tidspunkt må vi konkludere med at vi ikke forstår hvor plagene til pasienten kommer fra. Det er en ubehagelig løsning, for det kan virke som om vi gir opp. Det kan fremstå som en «enkel utvei» eller få oss til å føle oss inkompetente som leger. Og ikke minst - vi skuffer pasientene våre.

En diagnose fra psykiatrien som ofte blir brukt i slike situasjoner, er somatoforme lidelser. En av utfordringene med en slik diagnose er at pasienten føler at han/hun blir satt $i$ en psykiatribås som de ikke nødvendigvis kjenner seg igjen i. «Hvordan kan det være psykisk 
når jeg føler at det er fysisk?» er en reaksjon mange pasienter vil få, og den er berettiget. Et navn som virker å være i stadig økt bruk blant fastlegekolleger i Norge er MUPS. Det står for «medisinsk uforklarlige plager og symptomer» og er kanskje en ærligere variant. I en norsk studie fra 2014 fant man at pasienten i hele $3 \%$ av konsultasjonene til norske allmennpraktikere led av MUPS (1).

Uansett hva vi kaller det er det noen ganger viktig å innrømme at vi ikke vet. Det er en krevende diagnose å sette, rent medisinsk, for vi kan aldri utelukke absolutt alle sykdommer som kan føre til pasientens symptomer. Og når vi først har bestemt oss for at vi ikke klarer å løse problemet, da gjenstår den virkelige utfordringen: Å hjelpe pasienten.

Hjelpen består i å forklare at dette på ingen måte betyr at pasienten aldri vil bli bedre. Det er å vise at vi tar pasienten på alvor. At vi ikke påstår at «det sitter mellom øra» eller at det bare er pasienten som har litt «vondt i vilja».

Kanskje er det ikke så nyttig å si at vi ikke vet, men det kan faktisk ha en positiv effekt for pasienten. Å lete uten å finne svar kan være et tilleggsproblem som forverrer symptomene. Ved å være ærlig om at vi ikke vet, kan vi i alle fall fjerne den delen av å være syk. Og selv om vi ikke vet hva det er, har vi utelukket at det er noe livstruende. Pasienten må føle seg trygg på at vi har gjort alt som kan gjøres i vitenskapens navn for dem. Det siste er spesielt viktig, så de ikke blir fristet til å oppsøke potensielt livsfarlige alternative behandlingsmetoder.

Når vi slutter å utrede, kan vi konsentrere oss om å behandle symptomene. Målet er tross alt høyest mulig livskvalitet for pasientene våre. Det innebærer at vi noen ganger må finne hvordan man skal leve med plagene heller enn hvordan man skal kurere dem. I en Cochrane-analyse har man gjennomgått og analysert litteratur på effekt av forskjellige behandlingsmetoder ved MUPS (2). Den systematiske oversikten gir dessverre ikke noe sikkert svar på hva vi må gjøre.

Det dreier seg om en heterogen pasientgruppe med behov for individualisert oppfølging. Fysikalsk behandling, medisiner, sykmeldinger og andre tiltak må tilpasses den enkelte. Men første steget for å kunne hjelpe er å innse det selv og prøve å forklare pasienten på en skånsom måte at menneskekroppen noen ganger rett og slett er litt rar.

LITTERATUR:

1. Aamland A, Malterud K, Werner EL. Patients with persistent medically unexplained physical symptoms: a descriptive study from Norwegian general practice. BMC Fam Pract 2014; 15: 107. [PubMed][CrossRef]

2. Rosendal M, Blankenstein AH, Morriss R et al. Enhanced care by generalists for functional somatic symptoms and disorders in primary care. Cochrane Database Syst Rev 2013; 10: CDoo8142. [PubMed]

Publisert: 4. januar 2018. Tidsskr Nor Legeforen. DOI: 10.4045/tidsskr.17.0968

(C) Tidsskrift for Den norske legeforening 2020. Lastet ned fra tidsskriftet.no 